\title{
Impact of Teacher's Training on Interest and Academic Achievements of Students by Multiple Teaching Methods
}

\author{
Saira and Muhammad Hafeez \\ 1. Department of Education, University of Gujrat, Gujrat, Pakistan \\ 2 Research Scholar, Allama Iqbal Open University, Islamabad, Pakistan
}

\begin{abstract}
A research has been conducted to check the effects of teacher's training and teaching methods on academic achievements and interests of students at secondary schools in computer course. The population is divided into four groups; - lecture teaching method (control group), discussion teaching method (experimental method), inquiry teaching method (experimental group) and demonstration teaching method (experimental group). Each group has a sample size of 20 students. A pre-test before training of teachers and post-test after training of teachers for academic achievement and interests of students taught by four teaching methods have been conducted. The results of pre and post-tests are then analysed statistical tools of descriptive statistics and ANOVA test. The results of the study indicated that students' academic achievements and interests have been increased before and after the training of the teachers taught by lecture, discussion, inquiry and demonstration teaching methods. The demonstration teaching method was ranked $1^{\text {st }}$ and lecture teaching method was ranked last.
\end{abstract}

Keywords: Instructor; Learning Styles; School; Teaching Methods; Thinking skills

DOI: $10.7176 / \mathrm{JEP} / 12-07-02$

Publication date:March $31^{\text {st }} 2021$

\section{Introduction}

A training is a process to get the required skills for a particular subject. The training is a valuable practice for the teachers to enhanced their teaching skills. A trained teacher has more skills and techniques to be applied for the better academic achievements of learners (Ulla, 2018). A teacher having better teaching skills can also produce students interest in a particular subject (Giovazolias et al., 2019). Many researchers including (Supriatna, 2015; Ulla, 2017; Oliveira et al., 2019) stated the importance of teachers training. The teacher's training provides the solutions of educational problems (Schütze et al., 2017).

In this modern age, the teacher's training is an important requirement and essential component for all the educational activites including conducive learning environment, curriculum development and implementation and assessment (Zulfiqar, 2016). A trained and skilful teacher has more ability to teach the students and implement the various teaching methods successfully. When teachers apply the various teaching methods and techniques according to the acquired skills then students achieved higher academic results and the interest of the student is also increased (Wuryaningsih et al., 2019).

Education is necessary element of humanity and crucial for the development of a nation (Hafeez et al., 2020). To educate most of the population in a country, it is necessary to impart free education up to the secondary level. In Pakistan, education is almost free up to secondary level (Ahmad, 2014). The secondary education is the education given to children of aged 13-16 years (Ahmed, 2016). The primarily aims of secondary education are to train students for the sound abilities in reflective, scientific and critical thinking (van \& Janssen, 2019). Teaching is the learning process in which knowledge and informations are transferred to the children to understand the scientific process (Sivarajah et al 2019). A teacher is the facilitator to provide the guidance in the teaching-learning process (Obidike, 2017).

The teaching method represents the different stratigies by which an instructor delivers lecture to the pupils based on predefined instructional objectives (Buseri \& Dorgu, 2011). Omar et al., (2020) stated that the main objectives of teaching are to support learners for getting, retain and utilization of information, establishment of habits and development of attitudes and increased store of information and understanding of basic rules and principles of subject matter. 


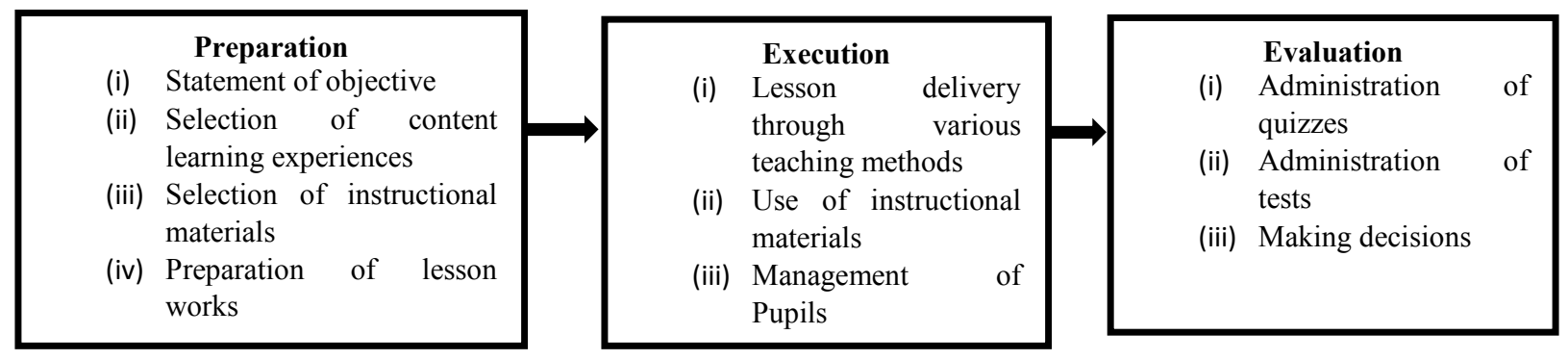

Figure. 1: Basic Components of Effective Teaching

To achieve the cognitive domain of learning of the learners, the psychologists developed various teaching methods and stratigies according to the cognitive domain of learners and learning situations (Mahasneh, 2020). Teaching and learning methods are key factors for the development of different educational fields (Al-Otaibi, 2015). The Training components for professional development of Teachers are shown in figure 1.

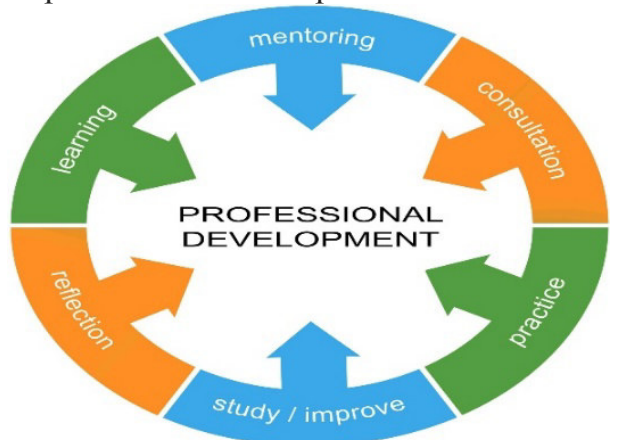

Figure.2: Training components for professional development of Teachers

The methods of teaching that stimulate active learning are based on the cognitive domain of learning. The learners must actively engage with the leaners activities. The active learning activities are also called as studentcentre activities or student-centre teaching. Some of the teaching methods that promote active learning are discussion method, inquiry method and demonstration method (Asmawati \& Malkan, 2020).

\section{Review of Literature}

\section{Teaching Methods}

The various teaching methods are listed below: -

\section{(i) Lecture Teaching Method}

A lecture teaching method is stated as the instructor continuously speaks before a group of students on a particular subject or topic. The group size may vary from 20 to 1000 . The instructor is responsible for delivering whole of the content of subject matter. It is one of the oldest teaching method used in schools, colleges and universities (Carson et al., 2001). The lecture method of teaching is based on the transfer of knowledge from instructor to the learners. The lecture method of teaching is also called traditional lecture or teaching method (White \& Kern, 2018). Many instructors believe that traditional lecture method is not more successful in the cognitive development of learners as traditional lecture method is a passive method of learning. It does not involve the learners to contribute in the educational process. Usually, instructor presents the whole lecture before the learners. The learners get the notes of the lecture and prepare them for the examination (Jungst et al., 2003). The major reason for adopting the lecture method of teaching is its ability to handle with large number of learners at a time (Marmah, 2014). The important characteristics of lecture teaching method are highlighted in figure 1 .

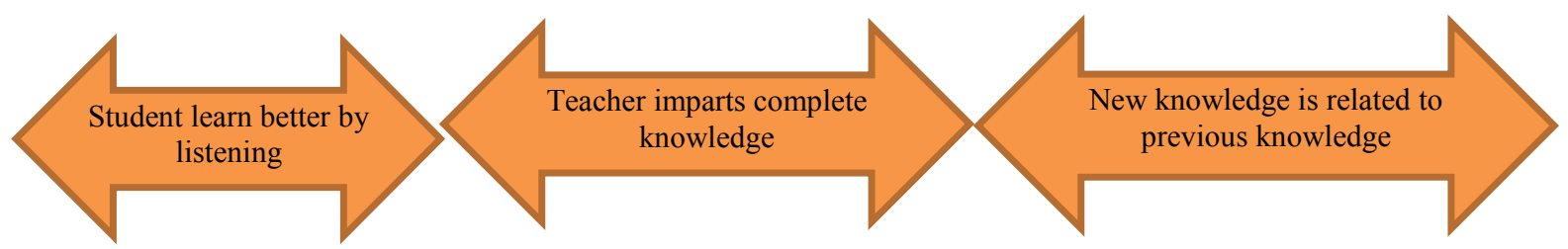

Figure.3: Characteristics of Lecture Method of Teaching

In the current age, the lecture teaching method is considered as the bored method because it does not active the students. However, it can be made effective by blending the information technology tools (Fulford \& Mahon, 
2018). Gooblar, (2019) argued that telling (lecture method of teaching) is an excellent method for the learners as in lecture method the instructor delivers all the contents with details.

\section{(ii) Discussion Teaching Method}

The discussion teaching method is a strategy which is used by groups for cooperative learning to get the desired educational objectives (Omoro \& Nato, 2014). The discussion is an activity in which the instructor divides the class and makes small groups of learners for active and cooperative learning on a specific topic or real-life problem. it is the process in which the learners are free to talk with eachothers and also with the instructor. The discussion teaching method is a learner-centred method in which the learners contribute their ideas actively (Yusuf, 2016). Rahman, et.al (2011) proposed in a study that discussion teaching method is the most valuable and applied teaching method all over the world in various fields of education. They also concluded that discussion teaching method improves the critical thinking skills, cognitive learning abilities, attitudes and speaking skills. The main characteristics of discussion teaching method are highlighted in figure 4 .

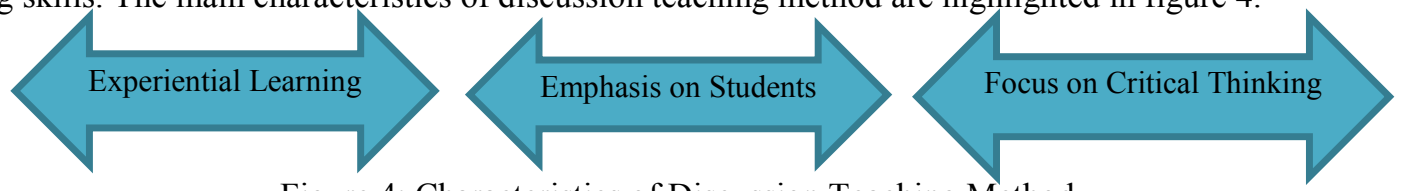

Figure.4: Characteristics of Discussion Teaching Method

Among available teaching methods, the discussion method appears to be the effective and most advanced teaching method. The discussion method of teaching is a type of strategy in which instructors and learners share their thoughts and ideas on a particular course content. The learning objectives are achieved by utilizing shared ideas among students and teachers (Eggen \& Kauchak, 2012). Paul et al., (2019) concluded in a study that discussion teaching method gives opportunity to the learners to interact with the instructor without any hesitation for clearly understanding the learning activites. The learners use their voices and listen other students respectfully and carefully to increase their learning abilities. It is an effective strategy to be used during the lecture.

\section{Role of Instructor in Discussion Teaching Method}

Leading the learners in constructive discussions in complex issues is a very difficult question in teaching (Sivarajah et al., 2019). The role of instructor is very important in discussion teaching method. An instructor must be good leader to lead the discussion and learners in the classroom. The learners may ask questions or comments during the discussion. A good leader has the ability to answers for all the questions raised by the learners. For all these challenges, the instructor must have a proper plan before the discussion session (Su et al., 2016). The instructor must be prepared for the bad comments in the discussion method (Abdulbaki et al., 2018). In discussion teaching method, the instructor may use different tools to conduct the discussion session. The tools may be projector, computer laptop for presentation and learning materials (Amalia, 2017).

(iii) Demonstration Teaching Method

In demonstration teaching method, the instructor acts as a principal and the learners watch the lecture with attention. It is also called as display or exhibition method of teaching. The demonstration teaching method includes the steps that how different things work (Ameh \& Dantani, 2012). The researchers (Teodora -Mihaela \& Laurentiu-Gabriel, 2014; Vrbik \& Vrbik, 2017) concluded in their studies that demonstration teaching method is the most suitable teaching method to improve and train the students learning and motor skills. Some researchers (Polizzotto \& Tamari, 2015; Basheer et al., 2017) also concluded that the demonstration teaching method has a positive effect on the learners and it also improves the cooperative learning level of the students. This teaching method is combined with other teaching methods to activate the learners and learning process.

Anwar\& Zulkifli, (2020) stated that the key objective of demonstration learning method is to exhibit and display the models and activites according to the learning materials through instructional media. In demonstration teaching method the instructor is the main character to display the activities. The main characteristics of demonstration teaching method are highlighted in figure 5.

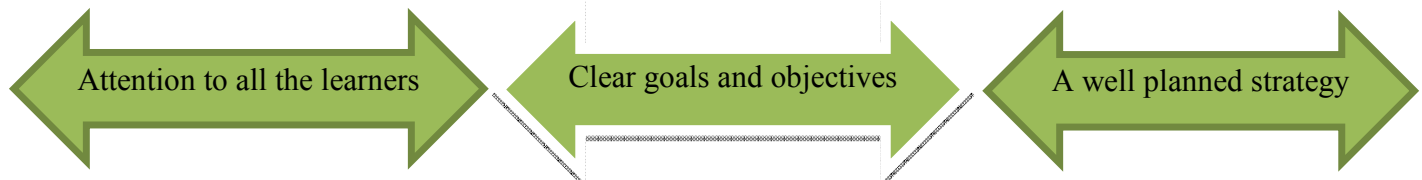

Figure.5: Characteristics of Demonstration Teaching Method

There are number of studies found in the literature to show the effectiveness of demonstration teaching method on learner's academic achievement in various disciplines. Furo et al., (2014) conducted a quantitative study to examine the various teaching methods including lecture, discussion, demonstration and inquiry methods on the students of primary and secondary schools. The conclusion of the research showed that the demonstration teaching method was the most appropriate method for the learners of primary and secondary schools. This method increases the critical thinking skills and cognitive domains of the learners. The authors also concluded 
that the lecture teaching method was the least accurate method.

Table.1: Advantages and Disadvantages of Multiple Teaching Methods

Teaching Advantages Disadvantages

- Widely used and accepted

- Facts and figures are told before the in a logical manner

- Useful for introducing new concepts

- Used to deliver the new learning

Lecture materials not yet accessible in the form of books or print

- Effective to transfer knowledge to a large group

- Useful for learners who learn and understand by listening

- Increases the interest for learning by discussing the topic of interest

- Develop critical thinking skills by discussion on a particular topic

Discussion

- Gives an opportunity to all the learners to express their views and transfer the knowledge

- Provides the platform for new thoughts and ideas

- Increases the critical thinking skills of the learners by thinking about the

Inquiry solution of problems

- The leaners take the ownership of learning process

- Increases engagement of the learners

- Helps to concentrate more efficiently towards learning

Demonstration

- The learners understand the concept in a best way to solve the real-life problems

- Improves the comprehension skills of the learners
- May not be useful to develop their cognitive and higher order thinking skills

- Stress on the creativity and thinking skills of learners

- Learners become passive

- No assessment for learners

- Information acquired forgotten quickly

- Instructor learns more than the learners

- May go into another direction rather than the topic chosen for discussion

- Time consuming process

- Course outlines may not cover

- Discussion session may be led by few and active participants and the remaining participants may be no advantage of discussion session

- Does not work well for all the scientific topics

- It requires more planning

- More skills are required to implement the inquiry teaching method

- Requires a proper place and equipment to perform the demonstration

- It may prove costly.

- May require some special skills that are not locally available

\section{(iv) Inquiry Teaching Method}

The inquiry teaching method is also called the discovery method. An inquiry is a procedure to understand the basic principles and concepts through the practice of observations, experiments and investigation (Shamsudin et al., 2013). The students learn by doing in the inquiry teaching method. The instructor guides the learners and also observes the activities of the students (Dorgu, 2016). The learners are engaged actively in the learning activities by following the scientific method to build their knowledge and to achieve their objectives (Dagnew \& Mekonnen, 2020). The learners try to discover new knowledge by finding the answers of questions by minimum guidance of the instructor in inquiry teaching method (FARAH \& Ayoubi, 2020).

Sylvanus \& Eke, (2017) categorized inquiry method of teaching into three types. (i) Open Inquiry method (ii) Structured Inquiry method (iii) Guided Inquiry method. In Open inquiry method, the learners find the problem, method to solve the problem and synthesis results. In Structured Inquiry method, the instructor guides for identified problem and provide materials as well as procedure related to the problem. In Guided inquiry method, the instructor only provide the problem and materials related to the problem. The learners their-selves identify the procedure to solve the problem and compile the results. The main characteristic of Inquiry teaching method are highlighted in figure 6.

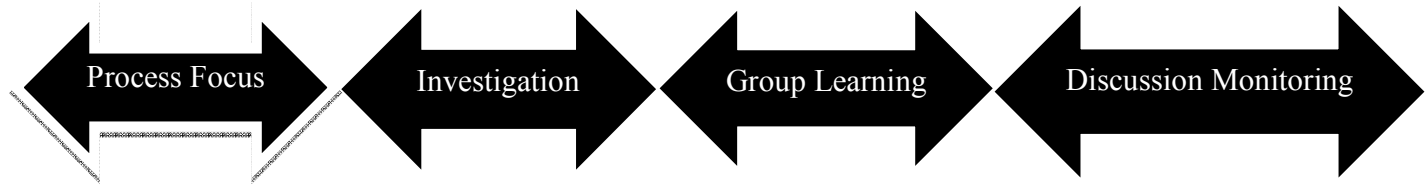

Figure.6: Characteristics of Inquiry Teaching Method 
Many researchers conducted researches to evaluate the inquiry teaching method. Suryanti et.al., (2018) directed a research to investigate usefulness of inquiry teaching method on the critical thinking skills of a primary school leaners. The results of the study showed that the inquiry teaching method is an effective way to increase the critical thinking skills of the learners. Sandika \& Fitrihidayah, (2018) led a research to examine the effect of inquiry learning method on scientific attitude and creative thinking of the learners in a secondary school. The study concluded that the inquiry teaching method enhanced the creative thinking and improved the attitudes of learners towards scientific knowledge. The main activities involved in inquiry teaching method are illustrated in figure 7.

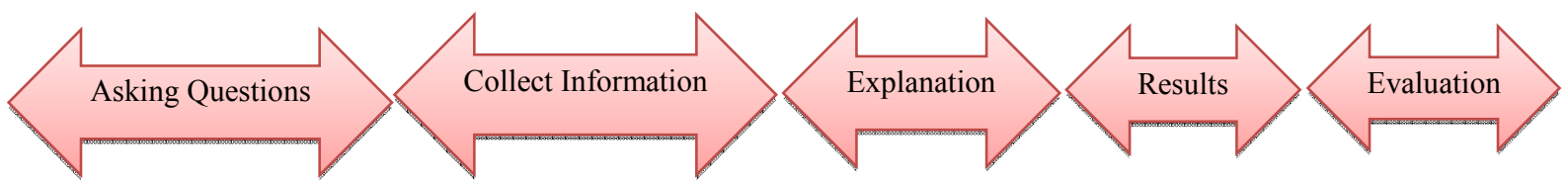

Figure.7: Activities Involved in Inquiry Teaching Method

\section{Teacher's Training, Multiple Teaching Methods and Students' Academic Achievement}

There is a close relation between the teacher's training, teaching methods and students' academic achievements. A trained teacher can apply multiple teaching methods and techniques in better way. Nzarirwehi et al., (2019) conducted a study to compare the academic achievements of students learnt from trained and untrained teachers. The outcomes of the research indicated that the pupils who learnt from the trained teachers got high academic achievements and the other students learnt from the untrained teachers got low academic achievements.

Behroz-Sarcheshmeh et al., (2017) investigated in a study that the trained teachers have better communication, teaching and critical thinking skills. They also concluded that students' academic achievement and interest improve when a trained teachers apply the teaching methods according to the classroom environment and situations.

Özüdogru, (2020) conducted a research to check the responses to the questions raised by students from trained and untrained teachers. The conclusion of the study indicated that the teachers who have done trainings responded the students in a better way as compared to the untrained teachers.

\section{Purpose of Study}

Many studies found in the literature in which accuracy of various teaching methods for the learners under various learning situation have been performed. But, there have been no study found in which multiple teaching methods have been assessed for academic achievement and interest of secondary school students. So, the objectives of current study are to review the various teaching methods, to assess the impact of teacher's training on academic achievements and interests of students in computer course of secondary school students.

\section{Hypothesis}

Ho: 1: No significance difference found between pre and post-test scores in academic achievements of pupils educated with four teaching methods in computer course.

Ho 2: No significance difference found between pre and post-test interest scores in computer course educated with four teaching methods.

\section{Methodology \\ Sample Size}

The research study followed the Quasi-experimental design and was done in Government Schools in Dera Ghazi Khan, Punjab Pakistan. A total of 300 learners for population were selected from twenty Government secondary schools for the research. As the number of schools were large, the multi stages sampling strategy was utilized to choose the sample for the research. By using the simple random sampling technique, a sample size of 100 learners were chosen from population. The sample size was divided into four groups namely; Control group (Lecture teaching method) 20 students, Experimental group I (Discussion teaching method) 20 students, Experimental group II (Demonstration teaching method) 20 students and Experimental group III (Inquiry teaching method) 20 students to assess the pre and post-test academic achievement scores and interest scores of pupils.

\section{Instruments}

The instruments used for collection of data were Computer Course Achievement Test (CCAT) and computer course Interest Scale (CCIS) which were authorized and validated by four experts from the Computer Science Department, Ghazi University, Dera Ghazi Khan. The comments and inputs from the experts enabled the 
researcher to produce final version of instruments. The reliability of instrument was constructed by using Cronbach alpha for CCAT and Kudder-Richardson-20 for CCIS. CCAT produced a value of 0.91 and CCIS produced a value of 0.87 .

\section{Data Collection}

The control and experimental groups were assigned to four class teachers. A pre-test for academic achievement and interest about subject was taken after assigning the groups. The teachers were trained for one week about how to teach the groups. After four weeks teaching, post-test was taken for academic achievement and interest about subject matter of control and experimental groups of learners. The data was collected from the results of pre and post-test of control groups and experimental groups. The data obtained from pre-test and post-test results were then analysed by statistical tools.

\section{Statistical Analysis}

The results of pre and post-test were analysed by using various statistical tools and ANOVA test. The ANOVA was applied to test the hypothesis. After using the ANOVA, if $p$ value obtained less that $0.05(\mathrm{p}<0.05)$, then hypothesis will be accepted (Ho accepted) and if the $p$ value obtained more than 0.05 , then hypothesis will be rejected (Ho rejected).

\section{Results}

Q1: What are the impacts of Lecture, Discussion, Inquiry and Demonstration teaching methods on academic achievement of students in computer course.

Ho 1: No significance difference found between pre and post-test scores in academic achievement of students educated with four teaching methods in computer course.

The statistical outcomes are illustrated in table 2. The outcomes indicate that mean academic achievement scores of students in pre and post- test taught by lecture teaching method ranges from 7.31-7.49 with standard deviation ranges from 2.39-2.56. The mean pre and post-test scores for academic achievements taught by discussion teaching method ranged from 8.21-9.91 and standard deviation ranges from 1.89-1.86. The mean pre and posttest scores for academic achievements taught by inquiry teaching method ranged from 6.89-10.19 and standard deviation ranges from 2.78-2.92. The mean pre and post-test scores for academic achievements taught by demonstration teaching method ranged from 7.96-14.20 and standard deviation ranges from 2.48-2.67. According to the statistical results, the mean gain values for lecture teaching method were $0.32,1.81$ for discussion teaching method, 3.29 for inquiry teaching method and 6.19 for demonstration teaching method. According to the gain value it can be concluded that the demonstration teaching method was ranked first in academic achievements of students in computer course and lecture teaching method was ranked last.

Table 2: Statistical investigation of Pre and Post-test scores of Academic Achievements by Multiple Teaching Methods

\begin{tabular}{llllllll}
\hline Method & $\mathbf{N}$ & Pre-test & \multicolumn{3}{l}{ Post-test } & \multirow{2}{*}{ Mean Gain } & \multirow{2}{*}{ Rank } \\
\cline { 2 - 6 } & & $\bar{X}$ & SD & $\bar{x}$ & SD & & \\
\hline Lecture (control) & 20 & 7.31 & 2.39 & 7.49 & 2.56 & 0.32 & $4^{\text {th }}$ \\
\hline Discussion (exp) & 20 & 8.21 & 1.89 & 9.91 & 1.86 & 1.81 & $3^{\text {rd }}$ \\
\hline $\begin{array}{l}\text { Demonstration } \\
\text { (exp) }\end{array}$ & 20 & 7.96 & 2.48 & 14.20 & 2.67 & 6.19 & $1^{\text {st }}$ \\
Inquiry (exp) & 20 & 6.89 & 2.78 & 10.19 & 2.92 & 3.29 & $2^{\text {nd }}$
\end{tabular}

$X=$ Mean; $\mathrm{SD}=$ Standard Deviation; $\mathrm{N}=$ Sample size 


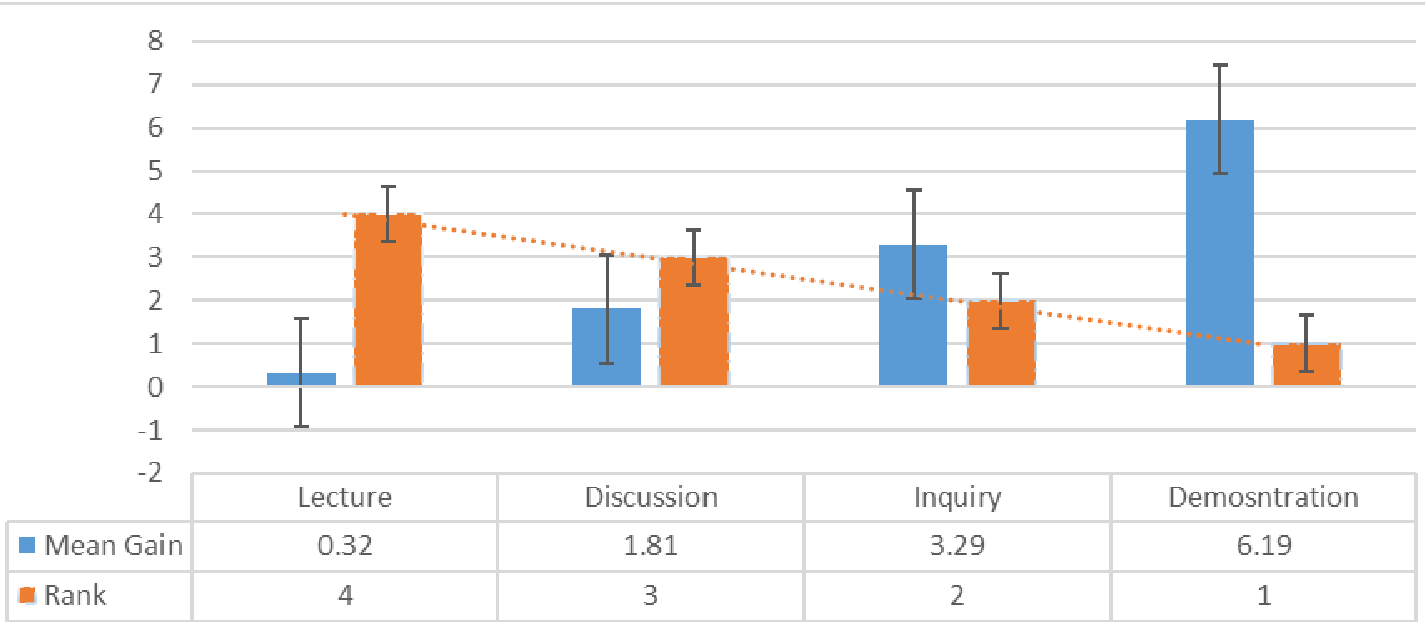

Figure.8: Graph between Mean Gain and Rank for academic achievements scores by using multiple teaching methods

Table.3: ANOVA for pre and post-test scores of students in academic achievements using multiple Teaching Methods

\begin{tabular}{lllll}
\hline \multicolumn{1}{c}{ Source } & Sum of Squares & Df & F & Sig \\
\cline { 1 - 3 } Between the groups & 14.2 & 3 & 0.718 & 0.591 \\
\cline { 1 - 3 } Within the groups & 26.374 & 4 & \\
\cline { 1 - 3 } Total & 40.574 & 7 & \\
\hline
\end{tabular}

Significance level $=0.05$

The results of testing hypothesis that no significance difference found between the pre and post-test scores in academic achievement of students taught with four teaching methods in computer course are shown in table 3 . According to the statistical results, the $\mathrm{F}$ value was 0.718 and $\mathrm{p}$ value was 0.591 . As the significance value is greater than the significance level of 0.05 so, the hypothesis that no significance difference found between pre and post-test scores in academic achievements of students taught with four teaching approaches in computer course is rejected.

Research Question 2: What are the impacts of Lecture, Discussion, Inquiry and Demonstration teaching methods on interest of students in computer course.

Ho 2: No significance difference found between the pre and post-test scores in interest of students educated with four teaching methods in computer course.

The statistical results are illustrated in table 4 . The results indicate that mean interests scores of students in pre and post- test taught by lecture teaching method ranges from 1.89-1.77 with standard deviation ranges from 0.780.82 . The mean pre and post-test scores of interests taught by discussion teaching method ranged from 2.10-2.35 and standard deviation ranges from $0.89-0.91$. The mean pre and post-test scores of interests taught by inquiry teaching method ranged from 2.05-2.31 and standard deviation ranges from 0.95-0.94. The mean pre and posttest scores of interests taught by demonstration teaching method ranged from 1.92-3.52 and standard deviation ranges from 0.64-0.83. According to the statistical results, the mean gain values for lecture teaching method were $-0.13,0.41$ for discussion teaching method, 0.65 for inquiry teaching method and 1.49 for demonstration teaching method. According to the gain value it can be concluded that the demonstration teaching method was ranked first in interests of students in computer course and lecture teaching method was ranked last.

Table.4: Statistical investigation of Pre and Post-test scores of interests in computer course by multiple

Teaching Methods

\begin{tabular}{|c|c|c|c|c|c|c|c|}
\hline \multirow[t]{2}{*}{ Method } & \multirow[t]{2}{*}{$\mathbf{N}$} & \multicolumn{2}{|c|}{ Pre-test } & \multicolumn{2}{|c|}{ Post-test } & \multirow[t]{2}{*}{ Mean Gain } & \multirow[t]{2}{*}{ Rank } \\
\hline & & $\bar{X}$ & SD & $\bar{x}$ & SD & & \\
\hline Lecture (control) & 20 & 1.89 & 0.78 & 1.77 & 0.82 & -0.13 & $4^{\text {th }}$ \\
\hline Discussion (exp) & 20 & 2.10 & 0.89 & 2.35 & 0.91 & 0.41 & $2^{\text {nd }}$ \\
\hline $\begin{array}{l}\text { Demonstration } \\
\text { (exp) }\end{array}$ & 20 & 1.92 & 0.64 & 3.52 & 0.83 & 1.49 & $1^{\text {st }}$ \\
\hline Inquiry (exp) & 20 & 2.05 & 0.95 & 2.31 & 0.94 & 0.65 & $3^{\text {rd }}$ \\
\hline
\end{tabular}

$X=$ Mean; $\mathrm{SD}=$ Standard Deviation; $\mathrm{N}=$ Sample size 


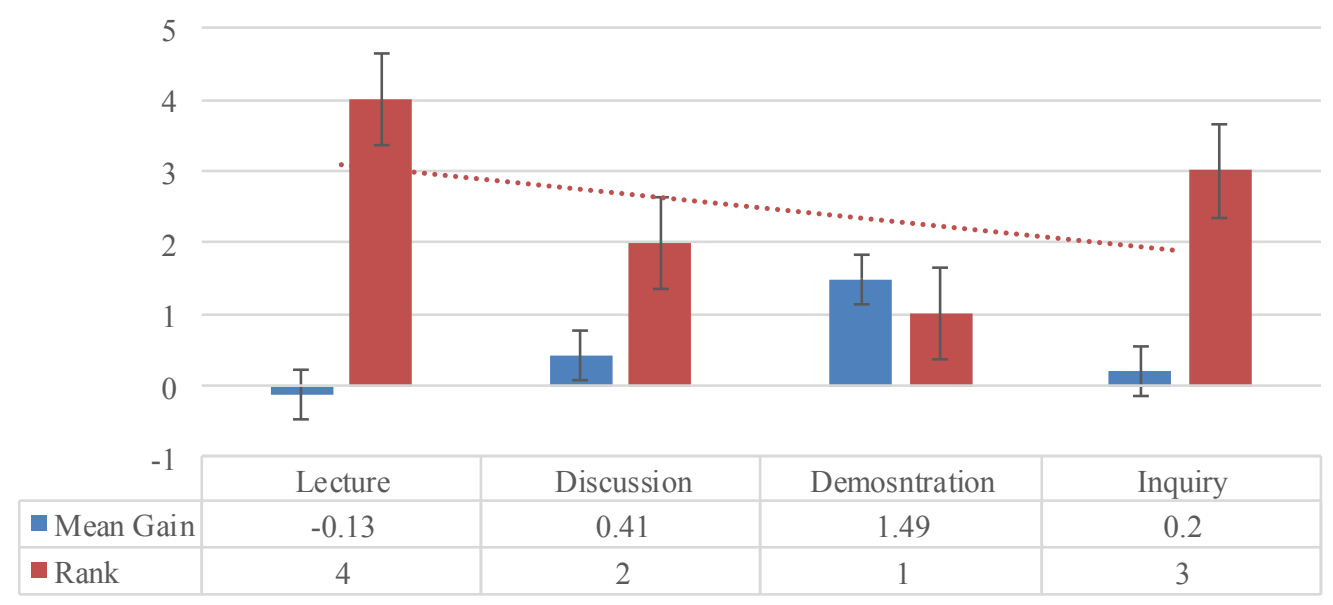

Figure.9: Graph between Mean Gain and Rank for interests scores by using multiple teaching methods

Table.5: ANOVA for pre and post-test scores of students in Interests Using Multiple Teaching Methods

\begin{tabular}{lllll}
\hline \multicolumn{1}{c}{ Source } & Sum of Squares & Df & F & Sig \\
\hline Between the groups & 0.804 & 3 & & \\
\cline { 1 - 3 } Within the groups & 1.352 & 4 & 0.793 & 0.558 \\
\cline { 1 - 4 } Total & 2.157 & 7 & & \\
\hline
\end{tabular}

Significance value $=0.05$

The results of testing hypothesis that no significant difference have been found between the pre and posttest scores in interest of students in computer science taught with four teaching methods in computer course are shown in table 5. According to the statistical results, the $\mathrm{F}$ value was 0.793 and significance value was 0.558 . As the significance value is greater than the significance level of 0.05 so, the hypothesis that no significance difference has been found between the pre and post-test scores in interest of pupils taught with four teaching approaches in computer course is rejected.

\section{Discussion}

Multiple teaching methods have been presented in the literature (Folounrunso \& Sunday,2017; Sivarajah et al., 2019; Kiker et al., 2020). Each teaching methods has its own requirements for implementation. A teaching method best at one place may be not fit for other place. To evaluate the teaching methods a study has been conducted. The lecture, discussion, inquiry and demonstration teaching methods have been used to assess the academic achievements in a computer course of secondary school students for pre and post- scores against each teaching method. The student's interests in computer course for pre and post- test scores are also assessed taught by four teaching methods. The scores of pre and post-test obtained by each teaching methods are statistically analysed.

The statistical results of impacts of lecture. Discussion, inquiry and demonstration on students' academic achievement showed that there was a significant increment in the post-test scores of the students by each teaching methods after one-week training of the teachers. The lecture teaching method was ranked last and the demonstration teaching method was ranked first for students' academic achievement in computer course in secondary schools. A research conducted by (Anthony \& Garner, 2016) resulted that the discussion, inquiry and demonstration teaching methods are better than the lecture teaching method where situations are favourable for applying these teaching methods.

The students interest towards computer course taught by lecture, discussion, inquiry and teaching methods are also assessed. The results indicated that after the training of teachers, the scores were better than before the traing. After traing the teachers taught the students in a better way and increased the interest of students towards the computer course in computer course. The statistical analysis of pre and post-test scores of student's interests in computer course were better in post-test. The demonstration teaching method was ranked first and lecture teaching method was ranked last for increasing the interests of students towards computer course in secondary schools.

\section{Conclusion}

A research is conducted to statistically assess the academic achievements and interest of students in computer course taught by four (Lecture, discussion, inquiry and demonstration) teaching methods. A pre and post- test is conducted to analyse the results. Pre-test is taken after assigning the control and experimental groups to each 
teacher. After the pre-test, one week traing is conducted for the teachers on how to teach the group by four teaching methods. After the traing, post-test has been taken. The statistical results of the study showed that academic achievements and interest of students towards computer course were better after the traing of teachers and demonstration method was ranked at first and lecture method was ranked at last.

\section{Recommendations}

The teachers must have trained to achieve the higher academic achievements and there should be continuously refresher courses for teacher's training.

\section{Limitations of the study and Future Research}

This research has been applied on the Government secondary school's students by selecting government school teachers on a small scale. The research can be done on a large scale for the province or for the whole country. The researcher can also be done on the primary school's students and teachers.

\section{Conflict of Interest}

No conflict of interest declared between the authors.

\section{References}

Abdulbaki, K., Suhaimi, M., Alsaqqaf, A., \& Jawad, W. (2018). The Use of the Discussion Method at University: Enhancement of Teaching and Learning. International Journal of Higher Education, 7(6), 118128. https://doi.org/10.5430/ijhe.v7n6p118

Ahmad, I. (2014). Critical Analysis of the Problems of Education in Pakistan: Possible Solutions. International Journal of Evaluation and Research in Education, 3(2), 79-84. http://dx.doi.org/10.11591/ijere.v3i2.1805

Ahmed, R. (2016). Social media integration in secondary education in Pakistan. Journal of Education and Educational Development, 3(1), 74-99. http://dx.doi.org/10.22555/joeed.v3i1.712

Al-Otaibi, S. (2015). Training needs for teaching staff members, effective teaching skills, faculty of Science, Princess Noura University. International Educational Journal, 12(6), 170-186. DOI: 10.18488/journal.61.2020.82.365.378

Amalia, R. (2017). Improving listening and speaking skills by using animation videos and discussion method. Pedagogy: Journal of English Language Teaching, 2(1), 30-36. https://ejournal.metrouniv.ac.id/index.php/pedagogy/article/view/652

Anthony, S., \& Garner, B. (2016). Teaching soft skills to business students: An analysis of multiple pedagogical methods. Business and Professional Communication Quarterly, 79(3), 360-370. https://doi.org/10.1177\%2F2329490616642247

Anwar, A. I., \& Zulkifli, A. (2020). The influence of demonstration method education in the knowledge of tooth brushing in children age 10-12 years. Enfermería Clínica, 30, 429-432. https://doi.org/10.1016/j.enfcli.2019.07.132

Asmawati, A., \& Malkan, M. (2020). Active Learning Strategies Implementation in Arabic Teaching at Senior High School. International Journal of Contemporary Islamic Education, 2(1), 1-20. https://doi.org/10.1016/j.enfcli.2019.07.132

Bardovi-Harlig, K., Mossman, S., \& Vellenga, H. E. (2015). The effect of instruction on pragmatic routines in academic discussion. Language teaching research, 19(3), 324-350. https://doi.org/10.1177\%2F1362168814541739

Behroz-Sarcheshmeh, S., Karimi, M., Mahmoudi, F., Shaghaghi, P., \& Jalil-Abkenar, S. S. (2017). Effect of training of life skills on social skills of high school students with intellectual disabilities. Practice in Clinical Psychology, 5(3), 177-186. http://dx.doi.org/10.18869/acadpub.jpcp.5.3.177

Buseri, J. C., \& Dorgu, T. E. (2011). The relevance of instructional materials for effective curriculum delivery in Nigeria. Journal of issues in professional Teacher Education (JTIPTE), 2(2), 9.

Carson, L., Edwards, H., Smith, B., \& Webb, G. (2001). Teaching power. Lecturing. Case studies, experience and practice. Kogan Page Limited, London, UK.

Dagnew, A., \& Mekonnen, D. (2020). Effect of using guided inquiry teaching method in improving grade eight students' concept of photosynthesis, primary school: Ethiopia. International Journal of Innovative Research in Education, 7(1), 01-15. https://doi.org/10.18844/ijire.v7i1.4655

Dorgu, T. E. (2016). Different teaching methods: A panacea for effective curriculum implementation in the classroom. International Journal of Secondary Education, 3(6), 77-87. 10.11648/j.ijsedu.s.2015030601.13

FARAH, N., \& Ayoubi, Z. (2020). Enhancing the critical thinking skills of grade 8 chemistry students using an inquiry and reflection teaching method. Journal of Education in Science Environment and Health, 6(3), 207-219. https://doi.org/10.21891/jeseh.656872

Folounrunso, B. E., \& Sunday, A. O. (2017). relative effectiveness of guided discovery and demonstration 
teaching techniques on students 'performance in chemistry in senior secondary schools in Ile-Ife, nigeria. European Journal of Education Studies. http://dx.doi.org/10.5281/zenodo.999983

Fulford, A. \& Mahon, A. (2018). The philosophical defence of the traditional lecture. Times Higher Education. Retrieved from https://www.timeshighereducation.com/blog/philosophicaldefence-traditionallecture\#survey-answer

Giovazolias, T., Syngelaki, E. M., \& Papastylianou, A. (2019). Effectiveness of a Teachers' Training Program on Their Core Self-Evaluations, Relationship with Students and Work Engagement. Journal of Classroom Interaction, 54(2).

Gooblar, D. (2019). Is it ever ok to lecture? The Chronicle of Higher Education. Retrieved from https://www.chronicle.com/article/Is-It-Ever-OK-to/245458

Hafeez, M., Kazmi, Q. A., Tahira, F., Hussain, M. Z., Ahmad, S., Yasmeen, A., ... \& Saqi, M. I. (2020). Impact of School Enrolment Size on Student's Achievements. Indonesian Journal of Basic Education, 3(1), 17-21. https://www.stkiprokania.ac.id/e-jurnal/index.php/IJOBE/article/view/302

Jungst, S., Licklider, B. \& Wiersema, J. (2003). Providing support for faculty who wish to shift to a learningcentered paradigm in their higher education classrooms. The Journal of Scholarship of Teaching and Learning, 3, 69-81.

Kiker, K., Eversman, S., Kruggel, H., \& Volkmann, C. (2020). Pioneering Orientation Using Multiple Teaching Methods and Low-Fidelity Simulation for Unlicensed Care Providers. Journal for nurses in professional development, 36(4), 213-220. doi: 10.1097/NND.0000000000000636

Mahasneh, O. (2020). A proposed model for the university students' e-portfolio. Journal of Education and eLearning Research, 7(1), 28-34. https://doi.org/10.20448/journal.509.2020.71.28.33

Marmah, A. A. (2014). Students' perception about the lecture as a method of teaching in tertiary institutions, views of students from college of technology education, Kumasi (Coltek). International Journal of Education and Research, 2(6), 601-612.

Nzarirwehi, J., \& Atuhumuze, F. (2019). In-Service Teacher Training and Professional Development of Primary School Teachers in Uganda. IAFOR Journal of Education, 7(1), 19-36.

Obidike, N.D. (2017). Factors affecting teacher quality practices in primary schools in Awka Education Zone, Anambra State. African Journal of Teacher Education 5(1), 1-8. https://doi.org/10.21083/ajote.v5i1.3519

Oliveira, C., Lopes, J., \& Spear-Swerling, L. (2019). Teachers' academic training for literacy instruction. European Journal of Teacher 315-334. https://doi.org/10.1080/02619768.2019.1576627

Omar, M. K., Mohammad, N. M., Shima, M. S., Raed, A., \& Ali, S. (2020). Favorite Methods of Teaching and Evaluation among Students in University Colleges. International Journal of Education and Practice, 8(2), 365-378. DOI: 10.18488/journal.61.2020.82.365.378

Omoro, B. \& Nato, L. W. (2014). Determining methods used in teaching geography in secondary schools in Rongo District, Kenya. International Journal of Academic Research in Progressive Education and Development, 3(1), 220- 232.

Özüdogru, M. (2020). The Use of a Student Response System in Teacher Training Classrooms and Its Effect on Classroom Environment. Acta Didactica Napocensia, 13(1), 29-42. https://doi.org/10.24193/adn.13.1.4

P. Eggen, D. Kauchak. Strategic and models for teachers: teaching content and teaching skills, Boston, Pearson Education, Inc, 2012.

Paul, P., Subramanyam, L., Raghunathan, G., \& Arumugam, B. (2019). Learner Perceptions Regarding the Lecture and the Small Group Discussion as Teaching/Learning Methods in Physiology". Bangladesh Journal of Medical Science, 18(2), 274-278. https://doi.org/10.3329/bjms.v18i2.40697

Polizzotto, K., \& Tamari, F. (2015). Using lecture demonstrations to visualize biological concepts. Journal of Microbiology \& Biology Education, 16(1), 79-81. https://doi.org/10.1128/jmbe.v16i1 .840

Rahman, F., Khalil, J. K., Jumani, N. B., Ajmal, M., Malik, S., \& Sharif, M. (2011). Impact of discussion method on students' performance. Int J Bus Soc Sci, 2(2), 84-94.

Sandika, Bayu \& Fitrihidajati, Herlina. 2018. Improving Creative Thinking Skills And Scientific Attitude Through Inquiry-Based Learning In Basic Biology Lecture Toward Students Of Biology Education. Indonesian Journal of Biology Education. Vol. 4 No. 1, http://ejournal.umm.ac.id/index.php/jpbi

Savela, T. (2018). The advantages and disadvantages of quantitative methods in schoolscape research. Linguistics and Education, 44, 31-44. https://doi.org/10.1016/j.linged.2017.09.004

Schütze, B., Rakoczy, K., Klieme, E., Besser, M., \& Leiss, D. (2017). Training effects on teachers' feedback practice: the mediating function of feedback knowledge and the moderating role of selfefficacy. ZDM, 49(3), 475-489. http://dx.doi.org/10.1007/s11858-017-0855-7

Shamsudin, N., Abdullah, N.,\&Yaamat, N. (2013). Strategies of teaching science using an inquiry-based science education (IBSE) by novice chemistry teachers. Procedia -Social and Behavioral Sciences,90, 583-592. https://doi.org/10.1016/j.sbspro.2013.07.129 
Sivarajah, R. T., Curci, N. E., Johnson, E. M., Lam, D. L., Lee, J. T., \& Richardson, M. L. (2019). A review of innovative teaching methods. Academic 101-113. https://doi.org/10.1016/j.acra.2018.03.025

Su, J. X., Cai, L. S., Chen, G., Dai, Y., Zhang, H. M., Gong, Z. L., \& Che, S. W. (2016). Exploration and Application of Discussion-based Teaching Method in Teaching of Medical Parasitology. Zhongguo ji sheng chong xue yu ji sheng chong bing za zhi Chinese journal of parasitology \& parasitic diseases, 34(5), 473475.

Suryanti, S., Arifin, S. Z., \& Baginda, U. (2018). The application of inquiry learning to train critical thinking skills on light material of primary school students. In Journal of physics: Conference series (Vol. 1108, No. 1, p. 012128).

Sylvanus, T., \& Eke, S. (2017). Effect of Inquiry Teaching Strategy on Academic Achievement of Senior Secondary School Chemistry Students in Okrika Local Government Area. International Journal of Education and Evaluation, 3(12), 9-14.

Teodora Mihaela, I., \& Laurentiu-Gabriel, T. (2014). Teaching approach to enhance motor skills for students in primary school, 746-751. https://doi.org/10.1016/j. sbspro.2014.09.314

Ulla, M. B. (2018). In-Service Teachers' Training: The Case of University Teachers in Yangon, Myanmar. Australian Journal of Teacher Education, 43(1), 66-77.

van Leeuwen, A., \& Janssen, J. (2019). A systematic review of teacher guidance during collaborative learning in primary and secondary education. Educational Research Review, 27, 71-89. https://doi.org/10.1016/j.edurev.2019.02.001

Vrbik, I., \& Vrbik, A. (2017). Video demonstration as a teaching method. Croatian Journal of Education, 19(2), 201-213. https://doi.org/10.15516/cje.v19i 0.2674

White, M. A., \& Kern, M. L., (2018). Positive education: Learning and teaching for wellbeing and academic mastery. International Journal of Wellbeing, 8(1), 1-17. doi:10.5502/ijw.v8i1.588

Wuryaningsih, W., Susilastuti, D., Darwin, M., \& Pierewan, A. (2019). Effects of Web-Based Learning and F2F Learning on Teachers Achievement in Teacher Training Program in Indonesia. International Journal of Emerging Technologies in Learning (iJET), 14(21), 123-147. https://www.learntechlib.org/p/217208/

Yusuf, H. O., Guga, A., \& Ibrahim, A. (2016). Discussion method and its effect on the Performance of students in reading comprehension in secondary school in plateau State. The Online Journal of Quality in Higher Education Vol.3, Issue 4. http://www.tojqih.net/journals/tojqih/ articles/v03i04/v03i04-01.pdf

Zulfiqar, M. S. (2016). Teachers' perceptions about in-service training at Federal Government Educational Institutions (Cantts/ Garrisons). Lahore:(Unpublished doctoral dissertation's thesis). Lahore: University of Education, Lahore. 